Wita Szulc

ORCID: 0000-0003-1938-780X

University of Zielona Góra

\title{
Does Art Therapy Need a Theory? Considerations on Terminology, Models and Paradigms of Art Therapy
}

\author{
Czy arteterapii potrzebna jest teoria? \\ Rozważania nad terminologia, modelami \\ i paradygmatami arteterapii
}

\begin{abstract}
The author discusses Polish publications on the theoretical foundations of art therapy published in Poland in chronological order and confronts them with the world literature of Art Therapy. One of the problems discussed in this paper is plagiarism in the Polish literature on Art Therapy, which is an obstacle on the way to Art Therapy achieving the status of science. The article covers such issues as sources of knowledge about Art Therapies, terminology, types, models and paradigms of Arts therapy. The aim of this article is to draw attention to the need for a critical approach to the available and disseminated sources of knowledge about the theory.
\end{abstract}

* Editorial note: Professor Wita Szulc, author of the article, passed away on 11 October 2021, aged 80.
KEYWORDS

Art Therapy,

bibliography in Art

Therapy research,

plagiarism in the

published Polish

literature on Art

Therapy, theories,

models, paradigms

StOWA KLUCZOWE

arteterapia,

bibliografia

w badaniach nad

arteterapiq, zjawisko

plagiaryzmu w polskim

piśmiennictwie

dotyczq̨cym

arteterapii, teorie,

modele, paradygmaty

SPI Vol. 24, 2021/4

ISSN 2450-5358

e-ISSN 2450-5366

DOI: 10.12775/SPI.2021.4.001

Submitted: 27.09.2021

Accepted: 22.11.2021

Articles and dissertations 


\section{ABSTRAKT}

Autorka omawia w porzqdku chronologicznym polskie publikacje na temat podstaw teoretycznych arteterapii i konfrontuje je z piśmiennictwem zagranicznym. Jednym z problemów, jakie podnosi, jest nierzetelność bibliograficzna pewnych polskich publikacji, która zdaniem autorki stoi na przeszkodzie do uzyskania przez arteterapię statusu nauki. W artykule omówiono takie zagadnienia jak źródła wiedzy o arteterapii, terminologię, rodzaje, modele i paradygmaty arteterapii.

\section{Introduction}

The question included in the title of this paper can be answered in the negative only by those who know little about therapy by means of art (which is a synonym of Art Therapy) and associate Art Therapy with casual activities provided to children, perhaps also for clients with decreased intellectual performance. The Polish literature on Art Therapy, which is expanding rapidly, is dominated by methodological approaches. The bulk of those publications are excerpts from B.A., M.A. and postgraduate theses (which is usually not explicated by the authors-there are some exceptions that prove the rule). The majority of the aforementioned publications start with a theoretical section, usually titled "Historical background." These authors begin their articles with a review of historical/selected sources of other authors under the guise of a discussion, using such words as "in the similar vein," "also," "in turn," "similarly" but, in reality, such "discussions" lack any selection of genuinely diversified opinions or views presented in the analyzed literature resources. In other words, the majority of literature in the Polish journals do not bear any resemblance to a real scientific dispute and little evidence for the author's critical thinking can be found in them.

The frequency of citations, or so the called impact factor is, to large extent a function of the online availability of a given publication, or piece of text and, not so much of the reputation of the author in the academic community. In other words, reputable scholars with decade-long track records may be, and frequently are omitted in the current literature citation algorithms and procedures, especially by younger generation authors simply because the older generation 
authors are not overly active online. Obviously, such situation is unfair and detrimental to the whole academic community. This phenomenon can be called "oblivion due to absence in the Internet." I would like to draw the attention to this phenomenon and point to the necessity of a critical approach to the current literature on Art Therapy, while bearing in mind that the quality of the current debate in the field of Art Therapy seriously suffers due to the fact that too many modern time publications (at least in Poland) in the field are simply oblivious to the theoretical foundations of Art Therapy, and omit the perspective presented and available in other, not so easily accessible resources. As a result, the Polish reader remains unaware of the contributions and works made by older generation authors whose contributions are "a mouse click away." I have long considered it regrettable that one can gain a reputation (at least in Poland) among Art and Music Therapy scholars through imposturous publishing practices and by omitting the contributions of the actual originator(s) of ideas and concepts.

\section{Knowledge sources and the application of Art Therapy}

Art Therapy is a unique form of non-pharmacological treatment, i.e. a therapy which requires the application of knowledge about art, humanity, culture and health. As a distinct domain of social practice, it is a synthesis of ideas and experiences deriving from such areas as visual arts, psychology and psychotherapy, pedagogy, and health sciences. Art therapy is orientated towards interpersonal communication, health and personal development. It has both practical and theoretical foundations. Since its beginnings in ancient times, Art Therapy has always been tightly connected with the treatment of mental diseases and medicine at large. In Poland, as in many other countries Art Therapy is applied as one of the techniques used by professionals in various fields, mainly psychologists but also physicians of different specialties, especially psychiatrists and to lesser extent anesthesiologists and cardiologists. The second wave of interest in Art Therapy came from teachers from special needs and regular schools as well as from organizers of cultural activities. In recent years, the spectrum of interest has widened substantially, for example, for patients suffering from post-traumatic stress disorder (PTSD) caused by combat 
experiences. Apart from hospitals and nursing homes, Art Therapy is practiced in day care centers, occupational therapy workshops, local cultural centers and in schools. Modern art therapy is gaining popularity within rehabilitation revalidation, the pedagogy of health, and social pedagogy. This is most observable in those forms of art therapy which focus on improving social integration of disabled persons, but also in its specific forms: addressed to the victims of domestic violence, underprivileged communities, and people suffering from social exclusion, war and terror.

The practical side of Art Therapy, which aims to help people with different kinds of developmental deficits and physical as well as psychological problems, has been known for a long time. What draws less attention of other practitioners is the theoretical foundations of art therapy, even though they let us understand the real role of the art therapist using arts as a therapeutic tool. By analyzing the rapid growth of interest in art therapy in the Polish literature, one can conclude that it is not accompanied by a deep reflection on the role of art in therapy (heteronomy vs. autonomy), on the cultural preferences within different domains and forms of art therapy, on cultural differences affecting how Art Therapy is used with clients from different social and cultural backgrounds, on the competences of the art therapist and, most of all, the methods of evaluating the results of art therapy which are imperative for the development of research in the field of Art Therapy. Only after a brief review of reports from countries with a longer tradition of using arts in therapy, where systematic research in the field has been conducted since the 1990s (Payne 1993; Gilroy 2006; de Witte 2021), but also considering the Polish publications in this field (Szulc, Furmanowska, Gładyszedwska-Cylulko 2010; Furmanowska 2014; Szulc, Łoza, Chmielnicka-Plaskota 2014; Bartel 2017; Szulc 2018), one can conclude that Art Therapy is a fully-fledged science, even though it has yet not gained such a status in Poland. It is a science based on a theory, or rather theories and the underlying models which will be discussed further. 


\section{The understanding and the etymology of the term art therapy in Poland}

From the viewpoint of the development of theory the question of terminology is valid. In recent years, that is since the beginning of the $21^{\text {st }}$ century, the term Art Therapy alone has become extremely popular and many people use it without giving much thought to its real meaning. Many of the definitions state that "it is therapy through art," which is a tautological expression. The understanding of the term "Art Therapy" and its essence as a coherent set of issues is relatively new to the field. It is worth remembering that the term "Art Therapy" has been used in Polish literature since the late 1980s but the concepts of applying art in different types of treatment, for example, for the mentally ill and for people with development disorders (Art brut), for bibliotherapy and music therapy, and even for silvotherapy and thalassotherapy (a therapy involving the use of seawater, spa therapy, and the salty ocean climate to improve overall health and well-being) appeared even earlier, in the 1960s and 1970s.

In 1988 the Karol Marcinkowski University of Medical Science in Poznan, Poland published the first issue of the book "Culture Therapy" (Szulc 1988), which highlights the relationship between character therapy and art therapy. In its original form, the term culture therapy is used in the following three meanings (Szulc 1988):

- as a form of psychotherapy used to fulfil certain therapeutic goals by means of cultural media, including art;

- as creating a friendly atmosphere conducive to the therapeutic process, including the use of photographs and other artistic artefacts. Such a concept of culture therapy predated the later form of culture therapy described in the 1990s, called "Art in Hospital" (Rebollo 1992);

- the third and most important meaning of Art Therapy takes the form of over ten applications of cultural media which include:

1. Art therapy (from Latin ars, artis), sometimes referred to as "visual art therapy"

2. Music therapy and its different variants: Light Therapy, Singing Therapy, Music Therapy, Choreotherapy (mousikefrom Greek) (choros-in Greek: a group folk dance), bibliotherapy (biblion Greek a book) and its variant: Poem Therapy. 
3. Drama therapy and psychodrama therapy (from Greek drao-I act) (a similar meaning can be found in Latin: ago).

4. Ludotherapy (from Latin ludus, ludi-play) including different kinds of play. The book (Szulc 1988: 30) also refers to some additional forms of culture therapy such as:

- Film Therapy,

- Photo Therapy,

- Edu Therapy,

- Aesthetics Therapy,

- Chimes Therapy,

- Chromotherapy.

As the above-mentioned typology was introduced by the author in 1988 which makes it the first ever mention in the world literature both in Poland and abroad. The term "Culture Therapy" to describe the different groups of therapies using a variety of forms of art as a therapeutic tool can be compared to the term "Expressive Therapies," used five years later by Cathy Malchiodi, who also referred to it as an "umbrella term" (Malchiodi 1993). A somewhat narrower concept popularly used in the United States is Creative Arts Therapies (CAT), which appeared during the first World Congress (medart International), which took place in 1992 in New York (Szulc 2021: 137-138), and also in the Netherlands (Houben, Smitskamp, de Velde 1993).

The same typology of different disciplines of art therapy, accompanied by the etymology of the Greek Latin and English terms was later presented in the amended issue of the book Kulturoterapia. Wykorzystanie sztuki i dziatalności kulturalno-oświatowej w lecznictwie (Szulc 1994: 15-16) ${ }^{1}$ [Culture Therapy: The Application of Art and

1 Exactly the same typology, in the form of a table, without any amendments, elaborations or extensions was published in a book in 2003 by E.J. Konieczna (2003) titled: Arteterapia w teorii i praktyce [Art Therapy in Theory and Practice] (and subsequent issues), page 16 without any references to the original source of this information. The typology was plagiarized by E.J. Konieczna in full from the original source, i.e.: the book by Wita Szulc: Kulturoterapia. Wykorzystanie sztuki i dziatalności kulturalno-oświatowej w lecznictwie (1994: 15-16) and, regretfully, without any intervention, apologies or a disclaimer from the Publishers (Oficyna Wydawnicza "Impuls" in Kraków). As a result, not only the intellectual rights of the original author have been violated but also the new generations of researchers and practitioners in the field of Art Therapy may draw the wrong and ungrounded conclusion that the author of 
Cultural Educational Activities in Medicine]. The term "art therapy" consists of two words. The first one comes from the Latin noun ars, which is not controversial, but is not appropriate to use in Polish the instrumental case (with what?) „sztuką" derived from the Latin adverb arte, which an accusative form of ars ("art," "skill") or doing something skillfully. ${ }^{2}$ Otherwise, the term "art Therapy" should be translated as: "a therapy of doing something professionally" - "something," meaning not necessarily "art." It is also worth mentioning that until 1988 in the Polish scholarly literature the Polish term "artoterapia" (with an "o") was used - as opposed to the current mainstream spelling in Polish: "arteterapia," which is in accordance with the Polish grammar rules. The letter „E” appeared later in other publications after 1989, justified by the Latin case (ablativus) of the noun ars-arte, i.e. (with art) and this translation has remained the dominant term until the present day. As far as the term therapy is concerned, it has been correctly derived from the Greek therapeuein, with the caveat

the above-mentioned publication (E.J. Konieczna) is the original source of the key concepts related to Art Therapy in Poland.

2 This philosophically ungrounded misconception about the term "Art Therapy" can be found in the book Arteterapia w teorii i praktyce [Art Therapy in Theory and Practise], p. 14 with a reference to the Encyclopedic vocabulary of Foreign Terms published in Warsaw in 1939 [Encyklopedyczny stownik wyrazów obcych], Warszawa 1939), Trzaska, Evert, Michalski, p. 121. The definitions of the terms "Therapy" and "Art" allegedly derived from the Longman Dictionary (with the errors in the bibliography are actually the translations taken from the book Kulturoterapia. Wykorzystanie sztuki i... (1994) pp. 18-19 but do not refer to this source. The violations of intellectual rights in the book by E.J. Konieczna do not limit themselves only to the plagiarism of original content but also to the intellectual rights for the translation into the Polish language, which should be marked in the main text in Polish with: "Cyt. za" (in this case: as cited in Szulc, 1994). In the opinion of the author, Art Therapy should be founded on solid ethical and methodological components. The only way to achieve this goal is to ensure the highest possible standards regarding the respect for the intellectual rights of the contributors to the development of Art Therapy. Unfortunately, in the current state of the matters in the Polish discourse on Art Therapy does not always support such standards, as demonstrated in the above-mentioned example. Obviously, the practitioners of Art Therapy do not necessarily have to know the etymology of the different terms used in the Art Therapy practise (for example, there are no such references in the seminal works by Cathy Malchiodi). However, if an author intends to present to the reader the broader context of each term, demonstrate his or her intellectual acumen, the literature review should be conducted with scientific curiosity and using bibliometric and physiometric competences. 
that it does not mean "to heal" in its current meaning but "together with a priest, to take care for" (Abramowiczówna 1960: 465). The word "therapist" comes from the Greek therapeutes, which means "somebody accompanying the priest," which is explained by the fact that in ancient times the treatment of patients was the responsibility of the priests. In modern times, the therapist is not involved in the treatment either but accompanies the physician, and looks after the patient. This is a distinction of paramount importance because it resolves the dispute over the role of an art therapist in the process of treatment in the situation when the physicians are adamant about calling art therapy procedures "(medical) treatment." A useful explanation for the practitioners in the field of art therapy, which started in the English-speaking countries, may be to refer to the Cambridge Dictionary of English regarding the terms "Art" and "Therapy" (Cambridge Dictionary 2021), which defines art as " making objects, images, music, etc. that are beautiful or that express feelings" and therapy as "a treatment that helps someone feel better, grow stronger, etc., especially after an illness." Interestingly the following are given as examples of therapy: "occupational therapy, speech therapy [logopedia in Polish], group therapy and [sic!] joining a club can be a therapy for loneliness."

\section{The broad and the narrow meanings of the term Art Therapy}

The distinction between the broad and the narrow meaning of the term "Art Therapy" was made for the first time in the book $\mathrm{Kul}$ turoterapia [Culture Therapy] in 1988 which is corroborated by the following quote: "In Poland one can observe the tendency to use the term "artoterapia" which combines music therapy, bibliotherapy and visual arts therapy jointly, and not limiting it, as is done in other countries, to art activities used in therapies for the sick, especially mentally ill" (Szulc 1988: 31). Two years later, Marian Kulczycki formulated the following definition of Art Therapy: "Art Therapy constitutes a set of views and activities directed at maintaining and/or increasing the quality of life by means of broadly defined pieces of art and artistic performance"(Kulczycki 1990: 7). Kulczycki also included different forms of amateur activities in art therapy, recommending that the main emphasis should be put on the use of renowned works 
of art. He was also of the opinion that art therapy should not be limited only to therapeutic and medical functions, but should also be used for education (Kulczycki 1990: 7).

The oldest Polish association of art therapists KAIROS $^{3}$ offers a very broad definition of art therapy on its official website due to the fact that it associates art therapists representing a very broad spectrum of interests and all types of therapy through art:

Art Therapy is an activity directed at a person and his/her social environment, aimed at restoring, improving or maintaining health and good quality of life, conducted by qualified persons. Art Therapy is characterized by the use of art, in its different forms, treated as a therapeutic tool and by a therapeutic relationship between the person conducting the therapy and his or her patient (Kairos 2021).

According to David Edwards's review of the different meanings of the term "Art Therapy" (Edwards 2004), there should be a clear distinction made between „Art Therapy" understood as therapy through art, and art understood as therapy. This distinction determines the identification of the main models of Art Therapy. The difference between "doing art," or artistic performance and Art Therapy lies in the relationship between the creator and the product of creative process. The outcome of the artistic performance of a patient is not subject to evaluation by other people, as is the case with the educational activities of students learning to become artists. Art Therapy is an expression of the subject's relationship with the world, his/her thoughts, fantasies and feelings, which could not have been expressed otherwise due to certain physical and mental limitations. Artists and other people involved in art, when looking at the outcomes of Art Therapy activities, tend to evaluate them using aesthetic criteria, something which an art therapist should refrain from doing because, as Margaret Naumburg, a pioneer of Art Therapy in the USA pointed out in the 1940s, the process of Art Therapy may occur because the majority of human thoughts and feelings in the subconscious mind are expressed in images rather than words. Art therapy techniques take advantage of the fact that every human being, both with and without an artistic background, has an intrinsic ability to project his/ her inner conflicts in a visual form (Dalley 1995: XIII). A similar

3 Stowarzyszenie Arteterapeutów Polskich „Kairos”. 
understanding of Art Therapy can be found in most of the later definitions, which are still considered valid and used by the American, British, Australian and New Zealand's associations of art therapists, which are also cited by the Polish scholars (Eoza, Chmielnicka-Plaskota 2014 33-58).

\section{Leading models and schools of thought in the contemporary Art Therapy}

The key questions that determine the identification of the main models of Art Therapy which appears in the discussions among the British and American theorists in the field is as follows:

What is the foundation of Art Therapy? Is it artistic performance in itself, or rather a verbal interaction focusing around the piece of art and the process of its creation, or perhaps a tight link between the two perspectives?

In the British and American scholarly literature on visual art therapy, developing since the 1980s one can distinguish three main schools of thought:

- analytical Art Therapy, focusing on the creative process: Margaret Naumburg (USA) was the precursor of this school of thought;

- Art Therapy based on art: the precursors of this school of thought where Edith Kramer in the USA and Adrian K.G. Hill in the UK,

- Artpsychotherapy which attaches equal weight to both the process of creation and the relationship between the therapist and the patient. This school of thought is most popular in the UK and in Germany where there is a clear distinction between Art Therapy and Artpsychotherapy (Waller 1998).

\section{Analytical Art Therapy}

The oldest and the most rudimentary form of art therapy is art therapy rooted in psychoanalysis. The essence of psychoanalysis is the interaction between the therapist and the patient during a conversation. According to the art therapists representing this school of thought, the use of artistic means of free expression with adults 
allows for a safe return to the time of childhood and the later phases of development and for clarification of current problems through experiences from the past so that the patient is empowered to react to the current difficulties accordingly (Edwards 2004). The patient is able to express his or her feelings through the language of symbols and metaphors and the therapist should be cautious about interpreting them because the patient is the only person who knows how to accurately interpret them. During such sessions, the art therapists should not expect from the patient to enter into a discussion on the outcome of his/her artistic creation. The relationship between the art therapist and the patient should be characterized by empathy, trust, openness and benevolence. An art therapist, according to Tessa Dalley, should be proficient both in the language of art and the language of the patient (Dalley 1984/1990). ${ }^{4}$ The first Polish book titled Arteterapia was published in 1990 by the UMCS in Lublin. It was devoted to Art Therapy of patients with mental problems (Kwiatkowska 1990). The first phase of the formation of the theoretical foundations of art therapy across the world was accompanied by a review of the art therapy teaching syllabuses. Such was the case in Poland too, when the Poznan University of Medical Science (Akademia Medyczna im. Karola Marcinkowskiego) as early as in the late 1980s introduced a course in culture therapy Culture Therapy at the Faculty of Health Sciences and the course Art in Medicine at the Faculty of Medicine. The curricula and the teaching methods, including teaching professional empathy through analyzing and contemplating art (Szulc 1989a), as well as analyzing artistic autobiographies created by elderly people with creative output (Szulc 2003: 506-510) drew the interest of international professionals associated with ECArTE (Waller 1995: 53-53; Kossolapow, Scoble, Waller 2003). Polish scholars dealing with visual art therapy in psychiatry, special needs pedagogy and rehabilitation developed the following theoretical models described in the first volume of the four-volume series titled: Arteterapia: Healing mechanisms in art therapy by Bartosz Łoza; A pattern of therapeutic interventions in art therapy by

4 The book has been published in several editions and translated into several languages and for many years was the benchmark and the basic academic handbook for Art Therapy in European universities. Later it was replaced by Handbook of Art Therapy by Cathy Malchiodi (available in Polish since 2014). 
Aleksandra Chmielnicka-Plaskota; A model of perception and creating artistic-a static values in the process of healing through art") (by Tomasz Rudowski); A model of learning socially accepted behaviors in the art therapy of socially maladjusted individuals by Tomasz $\mathrm{Ru}-$ dowski; and A model of rehabilitation in art therapy behavior by Janina Florczykiewicz.

\section{Art brut—creative activities of subjects with intellectual disabilities or mentally ill patients}

The term Art brut, in the Polish language refers to "rough, authentic art." Art brut artists do not imitate or enter into dialogue with mainstream art. Moreover, they often are not familiar with art because it exists beyond the perception of reality. Oftentimes, they are inspired by their inner world and intuition. For them, art is the only means of expression and emotions, at the same time allowing them to be present among "normal" people and make a foothold in the world of others. Psychiatrists dealing with psychopathology expression, such as Magdalena Tyszkiewicz (Tyszkiewicz 1994) use the pieces of (brut) art of their patients for therapeutic applications. For many years, this unique, yet the most rudimentary type of Art Therapy has occupied the attention of the association "Psychiatria i Sztuka im doktora Andrzeja Kowala" (Dr. A. Kowal's Psychiatry and Art Association) from Krakow, Poland. Extensive research in the field is conducted in the psychiatric hospital in Gniezno, Poland and in the Poznan University of Arts in Poznan, Poland by Robert Bartel (Bartel 2017).

\section{Phenomenology and the Gestalt psychology}

The main tenet of the Gestalt psychology is phenomenology which is the philosophy of values. Gestalt psychology takes the position of a holistic perception of a phenomenon. Phenomenology in holistic psychology was a response to positivism, a sign of protest against the philosophy of positivism in science. The "here and now" technique borrowed from Gestalt therapy is used in Art Therapy, especially in Germany. The main responsibility of the therapist using 
this type of therapy is to "pull the patient away" from ruminating a traumatic past and the fear of dissipating the future events. Instead, the therapist aims to focus the attention of the patient on the present time. Some of the Gestalt techniques used in Art Therapy include so called panoramic techniques, for example a panorama of life or a panorama of an illness. That patients are involved in painting (the most appropriate technique is mandalas), talk about their lives or even act out stories from their lives in order to better understand those stories (and themselves). Sometimes those techniques are combined with active bibliotherapy.

\section{Therapy through creativity}

Andrzej Wojciechowski is of the opinion that "therapy through creativity" is the most appropriate description of what we call Art Therapy. As early as in the 1980s, he claimed that therapy through art is that closest to the original Greek therapeuein - "to attend" or "to treat"). He also accepts the following definition of creativity by Antoni Kępiński (Terapia przez twórczośc): "Creativity is any conscious imposition of one's order onto the external world or any conscious imposition of one's order onto the surrounding world" (Kępiński 1979, qtd. in Wojciechowski 1989), and concludes that "the whole term therapy can be therefore explained as attending which allows for a conscious resisting through engaging one's own senses into the surrounding world, to the tendencies of dissolution, standstill and addiction... therapy through art is enacted in an interaction between the therapist and the person for whom he cares. The subjective balance is essential and the tool for therapy through art is everything which serves the "circle of hope."

Anita Stefańska raising the problem of standardization of art therapeutic activities addressed the issue of creativity in art therapy in the following manner: "Art Therapy is a bundle of different, longterm therapeutic interventions which consider creativity as one of the factors responsible for human development ... the basic tool of creativity used by the creative person, which needs to be emphasized, is the person himself: his/her thoughts, dilemmas, doubts and reflections mirrored in a more or less conscious way in the process of artistic performance (the symbolism of the inner world). The act of 
spontaneous creation allows us to immerse into the world of dreams and desires, but also the world of fears, grief and vulnerabilities. The outcome of therapeutic artistic intervention should be the acquisition by the patient or development of certain competences which constitute personal attitudes for his/her optimal life performance. The beneficiaries of this method are persons suffering from mental disorders, semantic disorders or social disorders (Stefańska 2008).

\section{Therapy through artistic creation}

Therapy through artistic creation describes artistic group activities (workshops) concentrated on the personal growth of the participants (Stefańska 2013). Such activities may also be offered to healthy people, and even to students of art colleges who have the opportunity to experience the benevolent influence of art. Wiesław Karolak, is one of the proponents of this school of thought. In his concept of Art Therapy, he emphasizes the importance of creativity. He admits that his views are similar to those of Virginia Satir, who is a very popular therapist in the United States, specializing in family therapy. She believes that "Therapy through art" is synonymous with "Therapy through creativity"- "Creative therapy." She associates "creative therapy" with "creating people" claiming that "creating people" shares many similarities with composing music or painting pictures. Creative therapy trades a human being as an inspiring medium for art and a creative therapist perceives his/her client holistically, considering their variability and stability, intellect and feelings.

\section{The theory of rehabilitation through sacred art by Tomasz Rudowski in the context of quantum psychology}

According to Tomasz Rudowski, treatment through sacred art with therapeutic tools is based on the value of messages incorporated in the images belonging to a religious cult or in the rituals of prayer, meditation and contemplation (Rudowski 2017: 181). The author of this interesting concept introduces an idea for a research model within the context of the set of different perceptions of the paintings The Stoning of Saint Stephen and Ecce Homo, the prayer and self-image. 
He refers to quantum psychology and criminal behavior influenced by an independent variable called "monitoring of the conscience."

\section{The theory of Salutogenesis. Art Therapy As a form of resistance against illness}

In his theory, Aaron Antonovsky (Antonowsky 1979) focuses on resilience resources in the salutogenic model of health. Contrary to medical research where the basic premise is pathogenesis, i.e. searching for the cause of illness, Antonovsky was convinced that the study of health was not the same as the study of disease. He claimed that the experience of health is a movement along a continuum of pain and suffering (ease/dis-ease). Life, according to Antonovsky, should be comprehensible, rational and controllable which then impacts the perceived quality of life. Even Ruud (1997) quotes a reputable Scandinavian scholar Siri Næss who defined the concept of «quality of life» through the following four main components: "1) Activity, which contains the dimensions of engagement, energy, self-realization and freedom.2) Good interpersonal relations which are realized through friendship and intimate relations. 3) Self-confidence, which has to do with self-esteem and self-acceptance, and 4) A basic sense of happiness which is maintained through emotional experiences, safety and joy." The Polish model of quality of life was embedded in the Health Sciences indicating parallels with Art Therapy as a broader sense (Szulc 1996).

\section{Engagement and social inclusion by means of art therapeutic methods}

This research line became popular in Poland in the second decade of the $21^{\text {st }}$ century. The most ardent and active follower is Małgorzata Siemież from the University of Lower Silesia in Wrocław. She combines the activities from several domains of Art Therapy, namely, music therapy, theatre therapy, film therapy, bibliotherapy and also culture therapy (Siemież, Aleksandrowicz 2011; Szulc 2011). 


\section{The concept and the model of culture therapy}

Culture therapy, the first Polish concept of therapy through the heart has already been addressed in the terminology section of this article. At this point, it is worthwhile to look at the first phase of its development (at the turn of the 1980s and 1990s), where it simply meant cultural and educational activities in healthcare centers considering the various needs and potentials of patients. It was further developed in other articles positioning culture therapy within psychology, education (Szulc 1982, 1998, 2014), and sociology (Szulc 1996). Based on the abovementioned contributions, we will present a model of culture therapy.

The culture therapy MODEL in the narrow meaning is a model of re-creational/artistic/educational activities conducted in healthcare/ rehabilitation/day care institution/center serving to meet the needs and participatory potential of ill, disabled and distressed people. The aim of such activities is to restore and/or improve their well-being, and, as a consequence, to improve their health and quality of life. Different culture therapy tools are used to achieve this goal. Consequently, it is safe to say that the model of culture therapy will be a template for practical implementation of the theory behind it. The aim of culture therapy activities in the above-mentioned facilities is congruent with their general mission and the main expectations of the patients which are achieving (regaining) their physical, psychological and social fitness (Szulc 1994: 67-154).

The therapy activities may be easily adopted to the needs of schools, as well as educational, rehabilitation and social care institutions. One has to bear in mind that those activities should be adjusted to the organizational culture and organizational goals of these institutions. All activities should provide a safe environment where all participants are praised, accepted, rewarded, encouraged, supported, maintained, not judged or compared to other people, where the individual feels safe and free from anxiety" (Maslow 1986: 59, cited in: Szulc 1994). We can observe that in the $21^{\text {st }}$ century, such a path of development, without using the term "culture therapy" has been adopted by many schools and cultural institutions. 


\section{Culture Therapy or Art Therapy?}

The difference between the two concepts can be ascertained by analyzing their definitions (Szulc 1989). The translation of the excerpts of the article by an American artist and art therapist Joan Erikson titled "The Art and Healing" (translated by a Polish translator: „Zdrowiotwórcze możliwości sztuki,” which literally means: "Health-giving abilities of Art") were published in 1989 in the conference proceedings organized by the Karol Lipinski Music Academy in Wrocław, the first of a series of three conferences on Art Therapy under the auspices of the Polish Ministry of Art and Culture in Radziejowice (Erikson 1979; Szulc 1989). The text became popular among Polish professionals and for many years, it was the most frequently cited article on art therapy in Poland. Despite its popularity, (due to numerous citations) it does not include a definition of art therapy but it plainly explains the viewpoint which boils down to the following issues:

- The negation of art psychotherapy or rather psychotherapy with an analytical approach aiming to constantly scrutinize, observe and analyze the client in order to get to his/her most intimate thoughts and problems;

- Approval of an approach in which the patient is encouraged to take interest in artistic activities, experiencing art and interacting with art, which, according Joan Erikson offers vast therapeutic potential.

However humanistic this approach is, there is no place here for evaluation, checklists, and the application of quantitative methods of measurement.

\section{Art Therapy as an object of scientific research}

Experiencing art therapy, that is everything which takes place during art therapy sessions is a complex issue. It involves the subjective perceptions and interpretations of the relationship between the patient, art and the art therapist at interpersonal and intrapersonal levels. Art Therapy is also an aesthetic process involving creativity, intuition, inspiration, intentionality and spiritual elements. They are all related to the inner state of mind. With my wealth of experience 
in the field of applied Art Therapy, dating back to the 1980s and my continuous involvement in this field (including supervising Ph.D. students, participation in numerous conferences in Poland and abroad, involvement in professional communities, having published several hundred of articles and books etc.) until 2021, I propose to the Art Therapy research community in Poland and abroad the following research questions deserving, in my opinion further investigation:

1. What is the meaning of art therapy to the patient? How important is the act of participating in art therapy? How can it be best described?

2. What are the most effective ways to analyze the art therapeutic experience, i.e. The process itself, its impact on the patient and its outcomes?

These two questions are closely interrelated. To answer them one has to consider which research paradigms, models, methods and research tools need to be applied in order to acquire such knowledge and subsequently develop one's language ${ }^{5}$ describing the phenomenon of therapy through art.

Knowledge understood as a body of interrelated facts consists of scientific knowledge and common knowledge. Scientific knowledge evolves thanks to the development of science and the application of the scientific method. It is accumulated, constantly evolving and changing thanks to the development of science. It occasionally goes through revolutionary changes due to the changes of the so-called paradigms. Common knowledge comes from everyday experience and from the performance of natural psycho-cognitive functions characteristic to every human mind. Both types of knowledge play a role in the academic discourse on the role of therapeutic experiences through art. Neither of these two types of knowledge can be excluded from the analysis. It seems however, that of the two types of knowledge that common knowledge dominates. For example, in one study (Skwarek, Szulc 2016) revealed the dominance of common knowledge over scientific knowledge among Polish teachers regarding the application of art therapy in education practice. According to Jan Fazlagić (Fazlagić 2016: 27), one's capacity to act is not only

5 For more on the importance of professional language in knowledge development refer to Foray (2002). 
a fraction of his/her knowledge but also of his/her ignorance. Mental models and heuristics (Senge 1990; Kahneman 2011; Fazlagić 2014) also have a crucial role in developing a deep understanding of the world. In the case of teachers, the acquisition of new knowledge is sometimes thwarted by their prior suppositions.

\section{Art Therapy as a science. The Art Therapy Paradigm}

Andrea Gilroy is one the leading theorists of Art Therapy in Europe, also known to the Polish audience through her frequent visits to conferences, open lectures, and the book translated into the Polish language (Gilroy 2009). She understands science as (Gilroy 2006: 80):

- the state of knowledge-knowledge is the antithesis of ignorance and false reasoning,

- a defined field of university study,

- something that can be studied and is learnable.

Having shared the views of Andrea Gilroy on the position of science, we may proceed to analyze some of the more specific issues. Let us begin with the paradigm of Art Therapy. According to Thomas Kuhn, the author of the seminal book The Structure of Scientific Revolutions (first published in 1962), a paradigm is "universally recognized scientific achievements that, for a time, provide model problems and solutions for a community of practitioners, i.e., what is to be observed and scrutinized" (Kuhn 1962). The main characteristics of science is using the scientific method. The paradigm of the scientific method is its recognition by the scientific community as a scientific method. A paradigm is something accepted here and now by the scientific world and is potentially subject to questioning and change, or even falsification.

\section{Art Therapy and the positivist model of scientific research}

For many years the positivist model was the foundation for the majority of research studies on art therapy. It is characterized by measurable stimuli and observable behaviors. Egon G. Guba and Yvonna S. Lincoln (1994) observed that positivism is founded on five assumptions: 
1. The ontological assumption - there is only one reality which can be divided onto smaller parts that can be subject to investigation. The whole is a simple collection of smaller parts which can be measured and quantified.

2. The epistemological assumption-the observer is separated from the observed object.

3. The predictability and generalizability assumption-what is true in a certain context may also be true also in other contexts. The emphasis is put on predictability, but not on comprehension.

4. The assumption about linear casualty-there is no cause without effect.

5. The axiological assumption about the value of freedom-it ensures that the research findings are free from any influence of any value systems. Moreover, the investigator uses controlled procedures in order to avoid the influence of such value systems.

Although the researchers in the field of music therapy were the first ones to question the applicability of the above-mentioned positive approach to art therapy, due to its humanistic and artistic nature which excludes the use of algorithms, they themselves seem to be committed to the traditional approaches to research. The question arises: why do most researchers in music therapy publish their research results using the positivist model as their guidepost? Over 40 years ago, when music therapy was at its infancy, it had to constantly prove that it has a positive impact on the patient and explain how this process works. Amir is of the opinion that the music therapists who follow the positivist route in their research do so simply to gain acceptance and recognition from the other disciplines of science (meaning mainly Medical Sciences). This is understandable, given the fact that they mostly work alongside physicians in hospitals. Therefore, the positivist approach is a means of legitimizing the professional position of art therapists among medical professionals. One of the recent evidence to support this view is the Evidence Based Music Therapy (EMB), which grew out of medical sciences in the 1990s. The same method was introduced to visual arts by Andrea Gilroy, which is exemplified by the title of the book (Gilroy 2006). It is worth mentioning that the introduction of evidence-based practice 
into nursing (and the path to recognizing nursing as medical practice was similar to the struggles of art therapists) was once questioned by Dr. Di Marks-Maran at the "The Future of Nursing" conference at the University of Durham. He claimed that it is the product of modernistic paradigm dominating in medicine and that the overall position of nursing as a science should be derived from quantitative and qualitative research in the field, taking under consideration the value systems exhibited by the patients, reflective knowledge from learning, intuition and tacit knowledge (Szulc 1998). Dr. Di Marks-Maran's views provoked a discussion over the paper From Cultural Education to Art Therapy [Od edukacji kulturalnej do arteterapii] (Szulc 1998) due to the fact that she started her unconventional paper on paradigms in nursing with a parable of the Lebanese poet Khahil Gibran titled "The Madman" (1918). ${ }^{6}$ The main message of the parable is that everything is subjective: what we call "madness" and what we call "sanity" is subjective. The parable was included in the content of several Art Therapy curricula in Polish universities (Szulc 2014: 146, 150; Szulc 2018: 160).

\section{The role of the researcher. A change of paradigm}

In the positivist model, the researcher aims to understand the phenomenon that is the object of investigation from an objective point of view. The researcher has a research plan from the outset and knows how to proceed. The research design, hypothesis and the research tools are selected ahead of time and do not change during the research process. The researcher is interested in the results rather than in the process itself; the explanation is more important than the description. The person (the participant of the art therapeutic process) is perceived as a passive object of research rather than as its active participant. Such an approach is in stark contradiction to the very idea of Art Therapy and there are probably no examples of research studies which would prove the applicability of such an approach. A radical change of mindset among the leading researchers in one discipline of science causes the evolution of a new paradigm. It tends

6 See for example: https:/quotepark.com/quotes/1902939-khalil-gibranonce-there-ruled-in-the-distant-city-of-wirani-a-k/ 
to evolve from a simple reality to a complex one, from a hierarchical order towards a multitude of existing orders and the dominating order emerges through the process of interaction among the different factors and the speed at which they change. Every part contains information about the whole and is capable of reproducing the original picture of the system in its original shape. Therefore, the whole is something more than a sum of its parts: every part contains the essence of the wholeness.

\section{Qualitative research in Art Therapy}

The philosophy and the principles of qualitative research are based on a new paradigm. The methodology of qualitative research which is well known in social science seems to be best suited for conducting research in the field of art therapy (as opposed to quantitative research). According to Roberts Stake, "qualitative researchers seek "understanding of the complex interrelationships," while quantitative researchers seek "explanation and control" (Stake 1995). Data collection and analysis take place simultaneously so that every part of the emerging reality is instantly subject to analysis. One can compare this to musical improvisation, where everything emerges from the "unknown" and the music therapist starts to create music from several elements such as sounds, rhythms, dynamics and timbre. In another visual art therapy, it can be a piece of music created under the supervision of the art therapist in a studio filled with different components and in a creative environment, such as Joan Erikson described years ago (Erikson 1979). The qualitative approach concentrates on the phenomenon. So, music therapists search for meaning behind what is visible. Their goal is to establish meaning for each participant of the music therapy session. In reality, the majority of research in the field worldwide uses the positivist model which is compatible with the dominant logic of medical science. The bias of many Art Therapy researchers towards quantitative research can be explained through the desire to find a common language with the mainstream medicine research. Dorit Amir (1993) demonstrated why this is a flawed approach and proposed an alternative new paradigm using the grounded theory that is already applied in ethnonursing (see for example: McFarland et al.2012). She was able to pinpoint the similarities with 
music therapy and its holistic relevance to the patients and music therapists themselves. According to Amir (1993), a broader application of qualitative methods may shed new light on art, beauty and the nature of music therapeutic profession. According to Eliot (2010), qualitative researchers treat the uniqueness of individual cases and contexts as important to understanding, while attempting to nullify context to find the most general and pervasive explanatory relationships. The interaction between the researcher and the context is crucial. Given the many similarities between our therapeutic process and qualitative research, what needs clarification is the definition of an art therapist. Should he or she also take the role of a researcher or should this role be ceded to somebody else?

\section{Summary}

This article has provided a broad review of the development of Art Therapy. Some historical threads have been introduced to provide a broader picture of the main issues discussed in the paper, including plagiarism. The discussion on how to identify the therapeutic effect of participation in Art Therapy continues, new threads are being injected into the discussion and new areas of research being are proposed, for example intersectionality (de Witte 2021). We have come a long way since Joan Erikson's speech and the subsequent article celebrating her $50^{\text {th }}$ anniversary as an artist-art therapist (Erikson 1979). Many developments in the societies and in the current state of the art have occurred but the views dating back to the late 1970s still resonate among many scholars and practitioners. The ideas brought to us by Joan Erikson are still vivid and resonate in the minds of many contemporary scholars, which includes the author of this article.

\section{Bibliography}

Abramowiczówna Z. (1960). Stownik grecko-polski, vol. 2, Warszawa: Państwowe Wydawnictwo Naukowe.

Aldridge D. (1996). Music Therapy: Research and Practice in Medicine. From out of Silence, London: Jessica Kingsley Publication. 
Aleksandrowicz R., Siemież M. (2011). Arteterapia w aktywizacji spotecznej $i$ zawodowej osób zagrożonych wykluczeniem, Wrocław: Wydawnictwo Naukowe Dolnośląskiej Szkoły Wyższej.

Amir D. (1993). "Research on Music Therapy: Quantitative or Qualitative?" Nordic Journal of Music Therapy, vol. 2, no. 2, pp. 3-10.

Antonovsky A. (1979). Health, Stress and Coping, San Francisco (CA): Jossey-Bass.

Bartel R. (2017). Arteterapia i rozwój osobisty. Teoretyczne i praktyczne aspekty terapii przez sztukę, vol. 2: Zagadnienia szczegótowe, Poznań: Uniwersytet Artystyczny w Poznaniu.

Bogus M. (2013). “Arteterapia a zajęcia szkolne,” in A. Stefańska (ed.), Arteterapia i twórczośc w przestrzeni psychosomatycznej, Poznań: Wydawnictwo UAM: pp. 13-23.

Cambridge Dictionary (2021), https://dictionary.cambridge.org/dictionary/ english/art [access: 10.10.2021].

Dileo C., Bradt J. (2009). "On Creating the Discipline, Profession, and Evidence in the Field of Art Therapy and Healthcare," Arts and Health. An International Journal for Research, Policy and Practice, vol. 1, no. 2, pp. $168-182$.

Dalley T. (ed.) (1995). Art as Therapy: An Introduction to the Use of Art as a Therapeutic Technique, London-New York: Routledge,

Edwards D. (2004). Art Therapy, London: Sage Publishing.

Eliot D. (2010). Ten Distinctions Between Quantitative and Qualitative Studies, TheListeningResource.com.

Erikson J. (1979). “The Arts and Healing," American Journal of Art Therapy, vol. 18 , no. 3, pp. 75-80.

Erikson J. (1989). “Arteterapia czy uprawianie sztuki na użytek zdrowia?” Selected by W. Szulc, Arteterapia. Zeszyt Naukowy Akademii Muzycznej im. K. Lipińskiego, no. 48, pp. 27-34.

Fazlagić J. (2009). "Wiedza 'teoretyczna' i 'praktyczna', Problemy Jakości, no. 2, pp. 14-16.

Fazlagić J. (2014). Innowacyjne zarzq̨dzanie wiedza, Warszawa: Difin.

Foray D. (2002). “The Development of Knowledge of Different Sectors: A Model and Some Hypotheses. A paper prepared for the "Knowledge Management in Education and Learning” Forum 18-19 March 2002, Randolph Hotel, Oxford.

Galińska E. (1989). "Muzykoterapia jako jedna z form terapii przez sztukę. Przyczynek do dyskusji na temat idei utworzenia Międzyuczelnianego Instytutu Arteterapii," Arteterapia. Zeszyt Naukowy Akademii Muzycznej im. K. Lipińskiego we Wroctawiu, no. 48, pp. 73-84.

Kahneman D. (2011). Thinking, Fast and Slow, New York: Farrar, Straus and Giroux.

Florczykiewicz J. (2011/2013). Terapia przez kreacje plastycznq w resocjalizacji recydywistów penitencjarnych, Kraków: Oficyna Wydawnicza „Impuls”. 
Gilroy A. (2006). Art Therapy Research and Evidence-based Practice, London: Sage Publishing.

Gilroy A. (2009). Arteterapia - badania naukowe i praktyka, trans. S. Sobczyński, Łódź: Wydawnictwo AHE.

Guba E.G., Lincoln Y.S. (1994). "Competing Paradigms in Qualitative Research," in N.K. Denzin, S. Lincoln (eds.), Handbook of Qualitative Research, London: Sage Publication, pp. 105-117.

Houben J., H. Smitscamp, J. de Velde (eds.) (1993). The Creative Process. Part 1: Application in Therapy and Education, Culemborg: Phaedon.

Kairos. (2021). www.kajros.pl.

Kossolapow L., Scoble S., Waller D., (eds.) (2003). Arts - Therapies - Communication: On the Way to a Communicative European Arts Therapy, vol. 1, Muenster-Hamburg-London: Lit Verlag.

Kuhn T. (1962). The Structure of Scientific Revolutions, Chicago (IL): University of Chicago Press.

Kulczycki M. (1990). “Arteterapia i psychologia kliniczna,” Arteterapia III. Zeszyt Naukowy Akademii Muzycznej im. K. Lipinskiego we Wroctawiu, no. 57, pp. 7-19.

Lapoujade C. (2005). "Arts in the Arts Therapies: A European Perspective. Preface," in S. Scoble, M. Ross, C. Lapoujade, The Arts in Arts Therapies: a European perspective, Plymouth: University of Plymouth Press, pp. VII-IX.

Lincoln Y.S., Guba E.G. (1985). Naturalistic Inquiry, London: Sage Publishing.

Łoza B., Chmielnicka-Plaskota A. (2014). "Definicje arteterapii,” in Arteterapia. Teoria, praktyka, projekty, vol. 1: Teoria, Warszawa: Difin, pp. 13-20.

Malchiodi C. (ed.) (2005). "Expressive Therapies: History, Theory and Practice," in C. Malchiodi, Expressive Therapies, New York: Guilford Press, pp. 1-15.

Malchiodi C. (2014). Arteterapia. Podręcznik, trans. E. Bochenek, Gdańsk: Harmonia Universalis.

Maslow A.H. (1986). W strone psychologii istnienia, trans. I. Wyrzykowska, Warszawa: Instytut Wydawniczy Pax.

Marks-Maran D. (1998). Reconstructing Nursing: Evidence, Artistry and The Curriculum. Conference core papers. Grey College University of Durham (UK), pp. 2-17.

McFarland M.R., Mixer S.J., Webhe-Alamah H., Burk R. (2012). "Ethnonursing: A Qualitative Research Method for Studying Culturally Competent Care across Disciplines," International Journal of Qualitative Methods, vol. 11, no. 3, pp. 259-279.

Rolvsjord R. (2004). “Therapy as Empowerment: Clinical and Political Implications of Empowerment Philosophy in Mental Health Practices of Music Therapy," Nordic Journal of Music Therapy, vol. 13, no. 2, pp. 99-11. 
Payne H. (ed.) (1993). Handbook of Inquiry in the Arts Therapies: One River, Many Currents, London: Jessica Kingsley Publication.

Ruud E. (1997). "Music and the Quality of Life," Nordic Journal of Music Therapy, vol. 6, no. 2, pp. 86-97.

Rudowski T. (2009). Studia nad arteterapiq w ujęciu aksjologiczno-psychologicznym, Warszawa: Zakład Poligraficzny Primum.

Rudowski T. (2013). Edukacja i terapia przez sztukę. Arteterapia w świetle teorii doznań transakcyjnych, Warszawa: Eneteia Wydawnictwo Psychologii i Kultury.

Rudowski T. (2017). Resocjalizacja przez sztukę sakralnq w kontekście psychologii kwantowej, Warszawa: Difin.

Senge P. (1990). The Fifth Discipline: The Art and Practice of the Learning Organization, New York: Doubleday/Currency.

Skwarek B., Szulc W. (2017). “Arteterapia w pracy pedagogicznej," Zeszyty Naukowe PWSZ im. Witelona, vol. 22, no. 1, pp. 93-107.

Stachyra K. (ed.) (2012). Modele, metody i podejścia w muzykoterapii, Lublin: Wydawnictwo UMCS.

Siemież M., Aleksandrowicz R. (ed.) (2011). Arteterapia w aktywizacji spotecznej $i$ zawodowej osób zagrożonych wykluczeniem, Wrocław: Wydawnictwo Naukowe Dolnośląskiej Szkoły Wyższej.

Stake R. (1995). The Art of Case Study Research, London: Sage Publications.

Stefańska A. (ed.). (2013). Arteterapia w wymiarze kreacji... poszukiwania, drogowskazy, refleksje, Poznań-Kalisz: Uniwersytet im. Adama Mickiewicza w Poznaniu.

Stige B. (2002). Culture-Centered Music Therapy, Gilsum (NH): Barcelona Publishers.

Szulc W. (1980). "Potrzeby kulturalne - potrzeby ludzkie," Litteraria. Teoria Literatury - Metodologia - Kultura - Humanistyka, vol. 12, pp. 172-182.

Szulc W. (1982). "Propozycja wprowadzenia nowego przedmiotu nauczania na Wydziale Pielęgniarskim Akademii Medycznej,” Medycyna - Dydaktyka - Wychowanie. Kwartalnik Akademii Medycznej w Warszawie, pp. 103-106.

Szulc W. (1988). Kulturoterapia. Skrypt dla studentów Wydziatu Pielegniarskiego Akademii Medycznej, Poznań: Wydawnictwa Uczelniane Akademii Medycznej.

Szulc W. (1989a). "Rola malarstwa w kształceniu wrażliwości pielęgniarek," Pielegniarka i Potożna, no. 7, pp. 11-13.

Szulc W. (1989b). “Arteterapia czy kulturoterapia?” Arteterapia. Zeszyt Naukowy Akademii Muzycznej im. K. Lipińskiego, no. 48, pp. 35-41.

Szulc W. (1994). Kulturoterapia. Wykorzystanie sztuki i dziatalności kulturalno-ośrwiatowej w lecznictwie, Poznań: Wydawnictwa Uczelniane Akademii Medycznej.

Szulc W. (1996). “Jakość życia a kulturoterapia. Ujęcie modelowe,” Pielęgniarstwo 2000, no. 2(25), pp. 13-16. 
Szulc W. (1997). "A Course of 'Culture Therapy' at the Faculty of Nursing and Health Sciences," in G.D. Majoor, C.P.M. van der Vleuten, P.A. Hansen (eds.), MedEd21: Account of Initiative for Change Medical Education in Europe for the 21 ${ }^{\text {st }}$ Century, Amsterdam: Thesis Publishers, pp. 167-171.

Szulc W. (1998a). "From Culture Education to Culture Therapy," in Nurse Education Tomorrow Conference. 9th Annual International Participative Conference. Abstract papers, p. 118.

Szulc W. (1998b). "Koncepcja kulturoterapii,” in L. Gapik (ed.), Postępy psychoterapii, vol. 1, Poznań: Interfund, pp. 92-97.

Szulc W. (2001). Sztuka w stużbie medycyny. Od antyku do postmodernizmu, Poznań: Wydawnictwa Uczelniane Akademii Medycznej.

Szulc W. (2005). Muzykoterapia jako przedmiot badañ i edukacji, Lublin: Wydawnictwo UMCS.

Szulc W. (2007) "The Conception of Art-Music-Culture Therapy in Poland: Education and Practice," in $5^{\text {th }}$ International Art Therapy Conference: Integrative Arts Therapy - Theory and Practice, Ljepaja, Latvia, July 12-15, pp. $47-49$.

Szulc W., Furmanowska M., Gładyszewska-Cylulko J. (eds.) (2010). Arteterapia jako dyscyplina akademicka w krajach europejskich. Uniwersytet Wrocłaruski w ECArTE, Wrocław: „Atut”; Wrocławskie Wydawnictwo Oświatowe.

Szulc W. (2011). Arteterapia. Narodziny idei, ewolucja teorii, rozwój praktyki, Warszawa: Difin.

Szulc W. (2011a). "Uniwersalizm arteterapii. Co łączy poszczególne dziedziny terapii przez sztukę?” in M. Siemież, R. Aleksandrowicz (eds.), Arteterapia w aktywizacji spotecznej $i$ zawodowej osób zagrożonych wykluczeniem. Wrocław: Wydawnictwo Naukowe Dolnośląskiej Szkoły Wyższej.

Szulc W. (2014). Arteterapia oparta na wiedzy. Wiedza przydatna organizatorom, nauczycielom i uczestnikom arteterapii, Warszawa: Difin.

Szulc W. (2015). "Arteterapia w poszukiwaniu tożsamości naukowej," Zeszyty Naukowe PWSZ im. Witelona w Legnicy, no. 14, pp. 91-101.

Szulc W., Furmanowska M., Gładyszewska-Cylulko J. (eds.) (2010). Arteterapia jako dyscyplina akademicka w krajach europejskich. Uniwersytet Wroctawski w ECArTE, Wrocław: „Atut”; Wrocławskie Wydawnictwo Oświatowe.

Waller D. (1998). Towards a European Art Therapy: Creating a Profession, Buckingham-Philadelphia (PA): Open University Press.

Wertheim-Cahen T. (1995). "Schools and Professionals in the Creative Arts Therapies," in Conference Proceedings of ECArTE Conference 14-17 September 1994, vol. 1: The Art Therapist, Hatfield: University of Hertfordshire, pp. 29-35. 
Wojciechowski A. (1989). "Terapia przez twórczość," Zeszyt Naukowy Akademii Muzycznej im. K. Lipińskiego we Wroctawiu, no. 48, pp. 61-67. de Witte M. et al. (2021). "From Therapeutic Factors to Mechanisms of Change in the Creative Arts Therapies: A Scoping Review," Frontiers in Psychology, vol. 12, no. 678397, https://doi.org/10.3389/ fpsyg.2021.678397 [access: 25.09.2021]. 